\title{
Accumulation of Polycyclic Aromatic Hydrocarbons from transplanted lichens Parmotrema dilatatum in the city of Abidjan (Ivory Cost)
}

\author{
${ }^{1}$ Department of Chemistry, University of Nangui Abrogoua(LTPCM), 02 Bp 801 Abidjan 02, Ivory Cost \\ ${ }^{1}$ Department of Chemistry, University of Nangui Abrogoua(LTPCM),02 Bp 801 Abidjan 02, Ivory Cost \\ ${ }^{1}$ Department of Chemistry, University of Nangui Abrogoua(LTPCM), 02 Bp 801 Abidjan 02, Ivory Cost \\ ${ }^{1}$ Department of Chemistry, University of Nangui Abrogoua(LTPCM), 02 Bp 801 Abidjan 02, Ivory Cost \\ ${ }^{1}$ Department of Chemistry, University of Nangui Abrogoua(LTPCM), $02 \mathrm{Bp} 801$ Abidjan 02, Ivory Cost
}

${ }^{1}$ Yacouba Zoungranan, ${ }^{1}$ Lynda Ekou, ${ }^{1}$ Tchirioua Ekou, ${ }^{1}$ Daniel Fane, ${ }^{1}$ Kouadio Dobi Brice Kouassi

Corresponding Author: Lynda Ekou, Department of Chemistry, University of Nangui Abrogoua (LTPCM), 02 Bp 801 Abidjan 02, Ivory Cost E-mail: ekou_lynda@yahoo.fr

Received date: 11 March 2018, Accepted date: 15 June 2018, Online date: 20 June 2018

Copyright: (C) 2018 Lynda Ekou. This is an open-access article distributed under the terms of the Creative Commons Attribution License, which permits unrestricted use, distribution, and reproduction in any medium, provided the original author and source are credited.

\begin{abstract}
Direct monitoring of air pollutants requires sophisticated equipment and techniques that are not often available for poor or developing countries. In this context, using of plant as biomonitoring of air's quality is an interesting alternative. Among these plants lichens as biomonitors has received increasing attention in recent years. They are frequently used as organisms for passive and active monitoring of air quality. They also have no cuticles to control the exchange of water, nutrients, gas and other particles with the external environment and they depend highly on nutrients from atmospheric sources, they absorb nutritive elements and pollutants through their entire surface. Their ability to absorb toxic pollutant into their thalli during long periods of time allows lichens to be the most useful indicator of air quality. In this study we have used lichen Parmotrema dilatatum as bioindicators to evaluate the air quality on Polycyclic Aromatic Hydrocarbons (PAHs) pollutants in Abidjan's town. Lichens were transplanted during 12 months (July 2015 - July 2016) throughout 09 sites. Our results show heterogeneous and fluctuating distribution of the PAHs whose concentration is low because their values are in ng/g order. The sites of AdjaméMacaci, Cocody ENS, and Yopougon Zone are the most polluted with higher concentrations of $51.892 \mathrm{ng} / \mathrm{g}$ for Indeno[1,2,3-cd]pyrene, $15.656 \mathrm{ng} / \mathrm{g}$ for Pyrene and $11.025 \mathrm{ng} / \mathrm{g}$ for Fluorenthene. The least contaminated site is Plateau Carena, whose PHAs concentrations are low and sometimes below the limit of detection. These results reflect the anthropogenic activities practiced within the sites.
\end{abstract}

Key words: Atmospheric pollutants, Lichen, Biomonitor, Polycyclic Aromatic Hydrocarbons, Bioindicator

\section{INTRODUCTION}

Atmospheric pollution is one of the major problems in urban environments(Sawidis et al., 2011; Donahue, 2018). Pollutants containing Polycyclic Aromatic Hydrocarbons (PAHs) come from different anthropogenic activities such as aluminum production (Söderberg process), production of coke and anodes, Incineration of household waste, manufacture of cement, bitumen. The cracking of oil issued from bitumen and synthesis of creosote used for the preservation of wood, combustion of fossil fuels in vehicular traffic, and energy production are also human activities that produce PAHs (Wegener et al., 1992; Ravindra et al., 2008; Colman Lerner et al., 2016). Among them transport is the main source of PAHs pollution (Mastral et al., 2003; Colman Lerner et al., 2016). Beside anthropogenic sources of PAHs, we have natural ones which are linked to the combustion of biomass (forest fires), volcanic eruptions and diagenesis (formation of sedimentary rocks) (Shukla and Upreti, 2009). These pollutants are mutagenic which make them genotoxic and cytotoxic. Therefore they can induce DNA damage and prokaryotes and eukaryote cells mutations(Lasat, 2002; Colman Lerner et al., 2014). The measurements of atmospheric pollutants require expensive technical equipment's which often unavailable (Ashwini et al., 2014). The use of living organisms in the studies, to assess the quality of environment is now accepted in many countries (Basile et al., 2012; Zoungranan et al., 2017). Lichens and moss have been widely used to monitor air pollution (Bargagli and Nimis, 2002; Bačkor and Loppi, 2009; Käffer et al., 2011; Bertuzzi et al., 2013; Foan et al., 2015; Cocozza et al., 2016). They provide reliable information on the quality and characteristics of the environment(Conti and Cecchetti, 2001; Pitcairn et al., 2006; Samdudin et al., 2013; Seed et al., 2013; Paolia et al., 2015). Biomonitoring methods (lichens, moss...) present more advantageous aspects than conventional ones, such as easy sampling, cheap equipment, and high degree of pollutants accumulation (Sawidis et al., 2011). Lichens accumulate airborne chemicals and polycyclic aromatic hydrocarbons (PAHs) pollutants by adapting their metabolism mainly according to the impact of pollution (Van der Wat and Forbes, 2015). The effects of air pollution on lichens have been recognized since by Nylander (1866), who used abundance data in order to measure the effects of atmospheric pollution (Samsudin et al., 2012). Lichen is a symbiotic association of a fungus (mycobiont) and a photosynthetic partner (photobiont) (Zoungranan et al., 2017). They can be considered as ecosystems themselves where theresulted interaction of partners in behavior and life forms are not found in the isolated partners (Oksanen, 2006; Pawlik-Skowronska and Bačkor, 2011), allowing them to live in habitats where they can't live alone previously (Kranner and Birtic, 2005; Kranner et al., 2008; Catalá et al., 2013).They are found on trees, rocks, in soils and even on weevils and giant Galapagos turtles (Lin et al., 2003)and can grow in extreme environments, such as deserts, and high alpine, and polar regions (Ahmadjian, 1995). Lichens have not cuticles to control the exchange of water, nutrients, gas and other particles with the external environment; they are highly dependent on atmospheric sources for nutrients and take up elements via their whole surface (Doğrul Demiray et al., 2012; Samsudin et al., 2012). These organisms are well known to accumulate and retain many varieties of contaminants (Fuga et al., 2008; Munzi et al., 2011). More recently, the use of lichens as biomonitors for organic air pollutants has been investigated in many countries including Portugal, Spain, Poland, Italy and India USA (Will-Wolf et al., 2017). 
The aim of this work was to assess and quantify the quality Abidjan town's air in terms of PAHs. Lichens are taken from a relatively unpolluted site, the geophysical and ecological station of Lamto, and transplanted throughout 09 sites of Abidjan city. Concentrations of eight (8) different PAHs (Fluoranthene, Pyrene, Benzo[k]fluoranthene, Benzo[a]pyrene, Indeno[1,2,3-cd]pyrene, Benzo[ghi]perylene, Benzo[a]anthracene, Benzo[b]fluoranthene) contained in the thalli of Parmotrema dilatatum were quantified.

\section{MATERIALS AND METHODS}

\subsection{Study area:}

The study was carried out in the city of Abidjan, located in the coastal region of Ivory Coast $\left(5^{\circ} 00^{\prime} \mathrm{N}-5^{\circ} 30^{\prime} \mathrm{N}, 3^{\circ} 50^{\prime} \mathrm{W}-4^{\circ} 10^{\prime} \mathrm{W}\right)$ whose surface is about 324 $\mathrm{km}^{2}$. This area is located in equatorial climate with an annual rainfall is of $1784 \mathrm{~mm}$ and a mean annual temperature of $27^{\circ} \mathrm{C}$. The main direction of winds is the south-west one. Abidjan city is the most populated regions in Ivory Coast. This town is suffering from very harmful environmental problems due to the atmospheric emissions of industries and emissions due to vehicles' motor.

\subsection{Lichen sampling}

Lichen Parmotrema dilatatum were collected in the geophysical and ecology station of Lamto $\left(6.13^{\circ}, \mathrm{N} ; 5.02^{\circ}, \mathrm{W}\right)$, located on Abidjan to Yamoussoukro precisely between Singrobo and Taabo, along bandama river. This area is a natural park whose surface is about 2500 ha. The lichen's harvest was carried out in tropical climate in which the annual temperature average is $28.28^{\circ}$. The annual precipitation average is about $1194 \mathrm{~mm}$ and the relative humidity of air is higher than 58\%. This reserve was chosen because, of two main reasons. Firstly it is an area which far from sources of pollution and secondly the species Parmotrema dilatatum is abundant and therefore the collection of sampling causes a very low impact on the density of natural population.

\subsection{Lichen transplantation}

Lichens were transplanted together with their substrate $2 \mathrm{~m}$ above ground, ensuring conditions similar to those in their natural habitat. Lichens were exposed in the study area for 12 months (July 2015 - July 2016). Samples were retrieved each 4 months and then analyzed. The study was conducted throughout 09 sites (Cocody ENS, Plateau Carena, Yopougon Zone, Treichville Port, Anyama Centre, Marcory Voltaire, Adjamé 220, Adjamé Macaci, Abobo Mairie) of Abidjan city (Figure 1). The sites are characterized by the presence of industrial activities including manufacturing and processing of metals, chemicals, plastics, agrifood, textile and soap factories. Pollutants are also released by punctual sources, such as car repair, plants, agricultural practices and vehicular traffic.
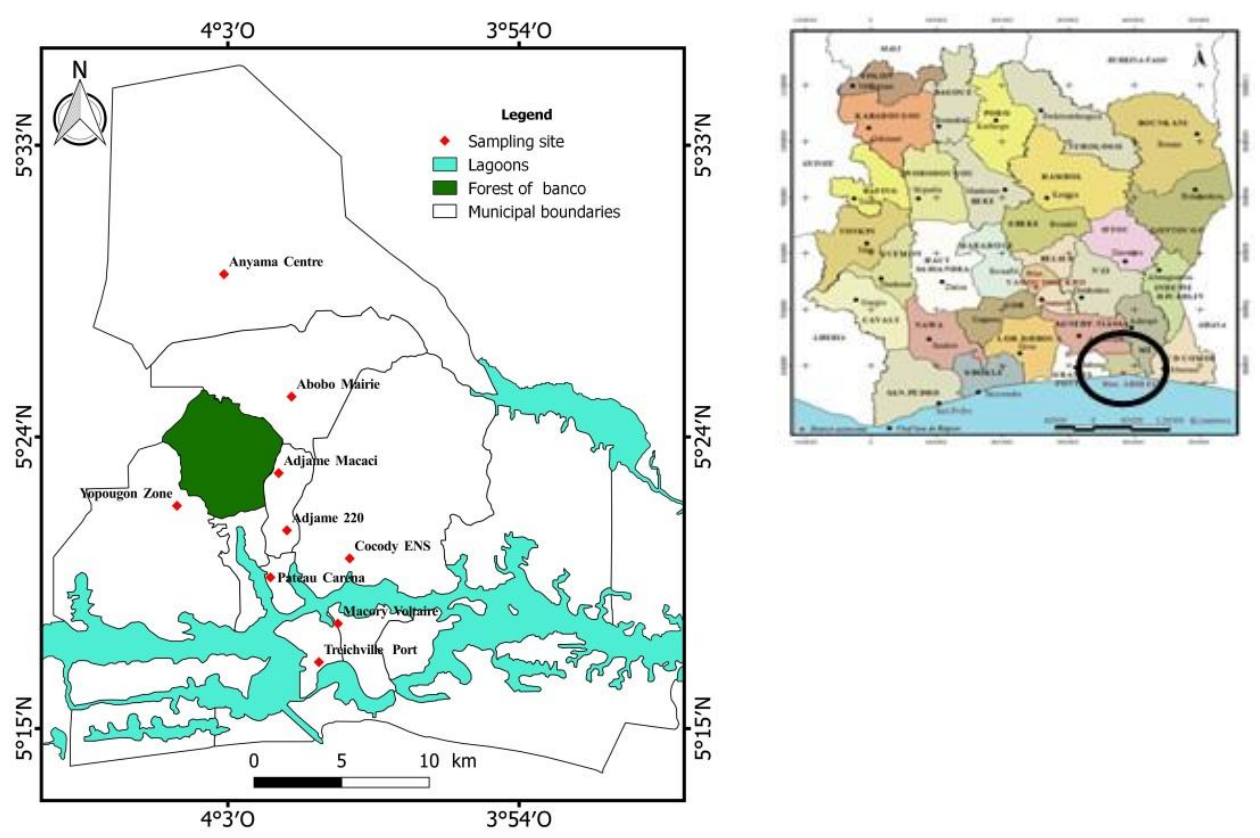

Fig. 1: Location of sampling sites in study area.

\subsection{PAHs determination in lichen:}

A quantity of lichens was taken and then dried at room temperature. Dried lichens were ground with a pestle and a porcelain mortar in order to get powder. Powdermass obtained is placed in a cellulose extraction cartridge (Whatman No 42) for extraction with a Soxhlet. A Volume of $180 \mathrm{~mL}$ of dichloromethane (DCM, analytical grade) is placed in a flask of $500 \mathrm{~mL}$ coated with aluminum film in order to prevent PAHs' photolysis. The extraction is carried out during $12 \mathrm{~h}$. The extract is then collected for the purification step. The purification is carried out in solid phase on a conditioned SPE purification column (Solid Phase Extraction). The samples were analyzed by a high-performance liquid chromatograph (Shimadzu HPLC) using Shimadzu VP-ODS column.

\section{RESULTS AND DISCUSSION}

\subsection{General analysis of PAHs:}

In this study, we interested ourselves to air pollution caused by PAHs during period of one year in Abidjan town. The determination of 8 PAHs (Fluoranthene(FLU), Pyrene (PYR), Benzo[k]fluoranthene(BkFLT), Benzo[a]pyrene (BaPYR), Indeno[1,2,3-cd]pyrene (IcdPYR), Benzo[ghi]perylene(BghiPL), Benzo[a]anthracene (BaANT), Benzo[b]fluoranthene(BbFLT)) contained in of Parmotrema dilatatum thalli was carried out every 4 months during a year. Our results show a heterogeneous and fluctuating distribution of the PAHs whose concentrations are low (around ng/g) (Figure 2). The observed discontinuity in results is due to the disappearance of a pollutant or to the appearance of a new pollutant on the same site during the four (4) following months. Dry and wet deposition depends on physical characteristics of the particles (size and shape), the meteorological conditions (wind speed, thermal stability), and morphological characteristics of the biological surface (Augusto et al., 2015; Kodnik et al., 2015). The PAHs can be oxidized with different kinetics according to their nature (Perraudin et al., 2005). Furthermore this large variation in total PAHs concentration is highly influenced not only by the existent source of pollution in the concerned site, but also many environmental factors, such as the seasons in which sampling was undertaken and the altitude at which samples were collected (Van der Wat and Forbes, 2015). Our observations are in agreement with studies conducted in Spain which show that the climate, the site having moist, dense forest, influence bioaccumulation of PAHs (Blasco et al., 2006).The PAHs concentration found in the present study are within the same range found in Sines (Portugal) in which concentrations range from 1 to $62 \mathrm{ng} / \mathrm{g}$ (Augusto et al., 2010).In the Tibetan Plateau (China) Zhou et al (2018) were obtained slightly higher values in the range of 38.0-133 ng/g. During all the study period, only Benzo[k]fluoranthene and Benzo[b]fluoranthene) were present at all sites. 

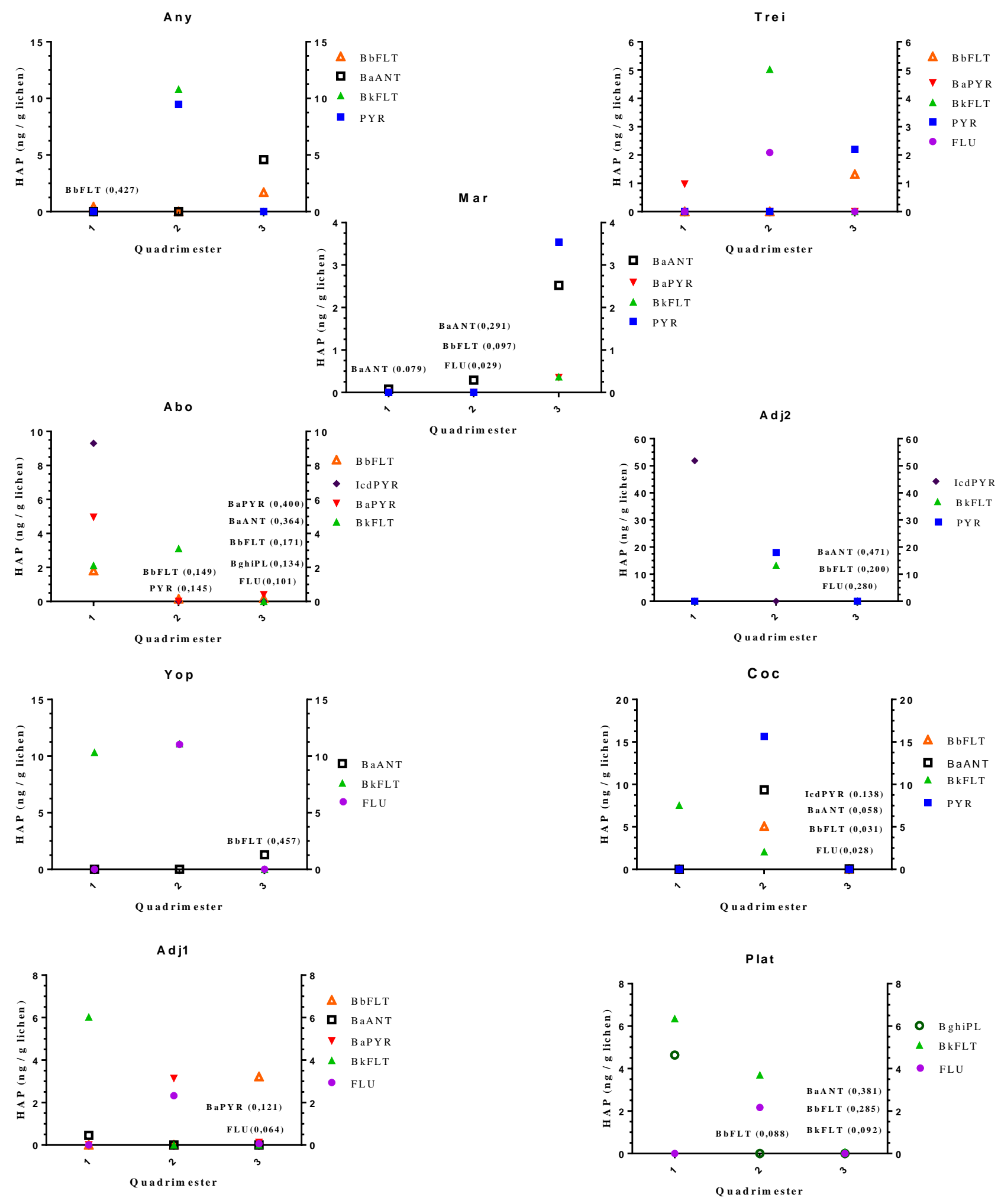

Fig. 2: Content of PAHs on the sites.

Coc : Cocody ENS ; Plat : Plateau Carena ; Yop:Yopougon Zone ; Trei : Treichville Port ; Any : Anyama Centre ; Mar : Marcory Voltaire ; Adj1: Adjamé 220 ; Adj 2 : Adjamé Macaci ; Abo : Abobo Mairie

\subsection{PAHs analysis per sites:}

Analysis of PHAs per site, show that Adjamé Macaci, Cocody, and Yopougon Zone are the most polluted ones with peak concentrations of 51.892 ng/g for Indeno[1,2,3-cd] pyrene, $15.656 \mathrm{ng} / \mathrm{g}$ for Pyrene and $11.025 \mathrm{ng} / \mathrm{g}$ for Fluorenthene. The least contaminated site is the plateau, whose PHAs contents are at the limit of detection.

It should be noted that these values are lower than those found by Shukla and Upreti (2009) in the bioaccumulation study of PAHs by lichen at DehraDun City (Garhwal Himalayas, India). They are in the order of $\mu \mathrm{g} / \mathrm{g}$. In Spain Domeño et al (2006) have found that total PAHs concentrations of is around $340 \mathrm{ng} / \mathrm{g}$ in lichen sampled near a river outside a city but total PAHs concentrations found is ranging 1.2 to1.65 $\mu \mathrm{g} / \mathrm{g}$ in an area with a high density of vehicular traffic. In northeastern Italy, Kodnik et al (2015) have obtained in thalli of lichen Pseudeverniafurfuracea, PAHs's concentrations in order from 48.22 to 272.73 ng/g in 
summer and from 289.73 to $1575.85 \mathrm{ng} / \mathrm{g}$ in winter. The presence of Fluoranthene at the sites of Yopougon and Plateau Carena is mainly related to the intense road traffic. Benzo[k]fluoranthene is coming from a pyrolytic source, produced by incomplete combustions of engine oils. It also presents in vehicular exhaust emissions (Wieczorek et al., 2015). The site Yopougon is closer to an international road. Benzo[ghi]perylene is present on the site of Plateau Carena. This presence could be linked to the wood processing activities, wood impregnation oils and naval handling activities (Blasco et al., 2011). The scarcity of Benzo[ghi]perylene in the study is due to the biotic process of its degradation. Indeno[1,2,3-cd]pyrene, Pyrene and Benzo[k]fluoranthene are of also from pyrolytic origin. These pyrolytic compounds are found on the site of Adjamé Macaci because it is characterized by the presence of extensive artisanal fish processing activities, high vehicular traffic, incomplete combustion of used wood and the incineration of household waste. Benzo[b]fluoranthene is present on the sites of Adjamé 220 and Cocody ENS and Abobo Mairie. This compound is from an anthropogenic origin specifically (Brignon and Soleille, 2006). The high Benzo[b]fluoranthene deposits, may be linked to the intensification of car traffic, the poor quality of transit vehicles (Domeño et al., 2006; Van der Wat and Forbes, 2015). In India, Blasco et al (2011) showed that the vehicular traffic essentially related to the origin of PAHs accumulation in lichens; These results are in line with other lichen biomonitoring studies, who showed profile pollution in presence of PAHs such as Fluoranthene, Pyrene, and Benzo[g,h,i] perylene (Maliszewska-Kordybach, 1996; Loppi et al., 2015).

\section{Conclusion:}

These studies have successfully exploited the effectiveness of lichen Parmotrema dilatatum asbiomonitor to diagnose PAHs pollutant in the environment of Abidjan city. The detected concentrations varied between industrial and urban areas. This specie of lichens can be used as a complementary system that integrates instrumental monitoring of air pollution. This result shows a heterogeneous and fluctuating distribution of PAHs. Their concentration are low and in the order of ng/g. This study shows that Adjamé Macaci, cocody, and Yopougon Zone are the most polluted sites. In these sites we found PAHs with different peaks of concentration such as $51.892 \mathrm{ng} / \mathrm{g}$ for Indeno[1,2,3-cd]pyrene, $15.656 \mathrm{ng} / \mathrm{g}$ for Pyrene and $11.025 \mathrm{ng} / \mathrm{g}$ for Fluorenthene. The least contaminated site is plateau, whose PHAs concentrations are low and sometimes below the limit of detection. Only Benzo[k]fluoranthene and Benzo[b]fluoranthene) were present in all the sites of our study area. The presence of these pollutants is dominated by vehicular traffic, industrial activities and human activities. It would be very interesting to carry out this study over a longer period, and to widen the range of PAHs studied and finally to propose a pollution mapping in PAHs of the different cities of Ivory Coast and to bring the necessary solutions to this scourge.

\section{ACKNOWLEDGMENTS}

We thank the officials of the geophysical and ecology station of Lamto for facilitating the collection of samples and the University of Nangui Abrogoua for their partially supporting

\section{REFERENCES}

Ahmadjian, V., 1995. Lichens are more important than you think. BioScience, 45(3): 124-124.

Ashwini, N.K., A.A. Kadam, M.S. Kachole and S.P. Govindwar, 2014. Lichen Permelia perlata: A novel system for biodegradation and detoxification of disperse dye Solvent Red 24. Journal of Hazardous Materials, 276: 461-468.

Augusto, S., C. Branquinho, C. Maguas, J. Matos and M.J. Pereira, 2010. Lichens as an integrating tool for monitoring PAH atmospheric deposition : A comparison with soil, air and pine needles. Environmental Pollution, 158(2): 483-489.

Augusto, S., J. Sierra, M. Nadal and M. Schuhmacher, 2015. Tracking polycyclic aromatic hydrocarbons in lichens: It's all about the algae. Environmental Pollution, 207: 441- 445.

Bačkor, M. and S. Loppi, 2009. Interactions of lichens with heavy metals. Biologia Plantarum, 53(2): 214-222.

Bargagli, R. and P.L. Nimis, 2002. Guidelines for the Use of Epiphytic Lichens as Biomonitors of Atmospheric Deposition of Trace Elements. In Monitoring with Lichens - Monitoring Lichens, 7: 295-299.

Basile, A., S. Sorbo, T. Pisani, L. Paoli, S. Munzi and S. Loppi, 2012. Bioacumulation and ultrastructural effects of $\mathrm{Cd}, \mathrm{Cu}, \mathrm{Pb}$ and $\mathrm{Zn}$ in the moss Scorpiurum circinatum (Brid.) Fleisch. Loeske. Environmental Pollution, 166: 208-211.

Bertuzzi, S., L. Davies, S.A. Power and M. Tretiach, 2013. Why lichens are bad biomonitors of ozone pollution.Ecological Indicators, 34: 391-397.

Blasco, M., C. Domeño, P. Lópeza and C. Nerín, 2011. Behaviour of different lichen species as biomonitors of air pollution by PAHs in natural ecosystems. EnvironmentalMonitoring andAssessment, 13: 2588-2596.

Blasco, M., C. Domeño and C. Nerín, 2006. Use of lichens as pollution biomonitors in remote areas: Comparison of PAHs extracted from lichens and atmospheric particles sampled in and around the Somport tunnel (pyrenees). Environmental Science and Technology, 40(20): 6384-6391.

Brignon, J.M. and S. Soleille, 2006. Données technico-économiques sur les substances chimiques en France: les HAP. Rapport de l'Institut National de l'Environnement Industriel et des Risques (INERIS), Paris, France, 1-45.

Catalá, M., F. Gasulla, A.E. Pradas Del Real, F. García-Breijo, J. Reig-Armiñana and E. Barreno, 2013. The organic air pollutant cumene hydroperoxide interferes with NO antioxidant role in rehydrating lichen. Environmental Pollution, 179: 277-284.

Cocozza, C., S. Ravera, P. Cherubini, F. Lombardi, M. Marchetti and R. Tognetti, 2016. Integrated biomonitoring of airborne pollutants over space and time using tree rings, bark, leaves and epiphytic lichens. Urban Forestry and Urban Greening, 17: 177-191.

Colman Lerner, J.E., T. Kohajda, M.E. Aguilar, L.A. Massolo, E.Y. Sánchez, A.A. Porta, P. Opitz, G. Wichmann, O. Herbarth and A. Mueller, 2014. Improvement of health risk factors after reduction of VOC concentrations in industrial and urban areas. Environmental Science and Pollution Research, 21(16): 9676-9688.

Colman Lerner, J.E., M.A. Orte, D. Giuliani, N. Matamoros, E.Y. Sanchez and A.A. Porta, 2016. Volatile and Semivolatile Organic Compounds Determination in Air. Comprehensive Analytical Chemistry, $73: 321-342$.

Conti, M.E. and G. Cecchetti, 2001. Biological monitoring: lichens as bioindicators of air pollution assessment - a review. Environmental Pollution, 114(3): 471-492.

Doğrul Demiray, A., I. Yolcubal, N.H. Akyol and G. Çobanoğlu, 2012. Biomonitoring of airborne metals using the Lichen Xanthoria parietina in Kocaeli

Province, Turkey. Ecological Indicators, 18: 632-643.

Domeño, C., M. Blasco, C. Sánchez and C. Nerín, 2006. A fast extraction technique for extracting polycyclic aromatic hydrocarbons (PAHs) from lichens samples used as biomonitors of air pollution: Dynamic sonication versus other methods. Analytica Chimica Acta, 569(1-2): 103-112.

Donahue, N.M., 2018. Air Pollution and Air Quality. In Green Chemistry: An Inclusive Approach, (Elsevier), pp: 151-176.

Foan, L., M. Domercq, R. Bermejo, J.M. Santamaría and V. Simon, 2015. Mosses as an integrating tool for monitoring PAH atmospheric deposition: Comparison with total deposition and evaluation of bioconcentration factors. A year-long case-study. Chemosphere, 119: 452-458.

Fuga, A., M. Saiki, M.P. Marcelli and P.H.N. Saldiva, 2008. Atmospheric pollutants monitoring by analysis of epiphytic lichens. Environmental Pollution, 151(2): 334-340.

Käffer, M.I., S.M.D.A. Martins, C. Alves, V.C. Pereira, J. Fachel and V.M.F. Vargas, 2011. Corticolous lichens as environmental indicators in urban areas in southern Brazil. Ecological Indicators, 11(5): 1319-1332.

Kodnik, D., F. Candotto Carniel, S. Licen, A. Tolloi, P. Barbieri and M. Tretiach, 2015. Seasonal variations of PAHs content and distribution patterns in a mixed land use area: A case study in NE Italy with the transplanted lichen Pseudevernia furfuracea. Atmospheric Environment, 113: 255-263.

Kranner, I., R. Beckett, A. Hochman and T.H. Nash, 2008. Desiccation-Tolerance in Lichens: A Review. The Bryologist, 111(4): 576-593.

Kranner, I. and S. Birtic, 2005. A Modulating Role for Antioxidants in Desiccation Tolerance. Integrative and Comparative Biology, 45(5): 734-740.

Lasat, M., 2002. The hazardous substance research centers program: An EPA perspective. Environmental Progress, 21(4): D2-D3.

Lin, X., Y.J. Cai, Z.X. Li, Q. Chen, Z.L. Liu and R. Wang, 2003. Structure determination, apoptosis induction, and telomerase inhibition of CFP-2, a novel 
lichenin from Cladonia furcata. Biochimica et Biophysica Acta - General Subjects, 1622(2): 99-108.

Loppi, S., K. Pozo, V.H. Estellano, S. Corsolini, G. Sardella and L. Paoli, 2015. Accumulation of polycyclic aromatic hydrocarbons by lichen transplants: Comparison with gas-phase passive air samplers. Chemosphere, 134: 39-43.

Maliszewska-Kordybach, B., 1996. Polycyclic aromatic hydrocarbons in agricultural soils in Poland: preliminary proposals for criteria to evaluate the level of soil contamination. Applied Geochemistry, 11(1-2): 121-127.

Mastral, A.M., J.M. López, M.S. Callén, T. García, R. Murillo and M.V. Navarro, 2003. Spatial and temporal PAH concentrations in Zaragoza, Spain. The Science of the total environment, 307(1-3): 111-124.

Munzi, S., S. Loppi, C. Cruz and C. Branquinho, 2011. Do lichens have "memory" of their native nitrogen environment Planta, $233(2)$ : 333-342.

Nylander, W., 1866. Les lichens du Jardin du Luxembourg. Bulletin de la Société botanique de France, 13: 364-372.

Oksanen, I., 2006. Ecological and biotechnological aspects of lichens. Applied Microbiology and Biotechnology, 73(4): 723-734.

Paolia, L., S. Munzib, A. Guttovác, D. Senkoc, G. Sardellad and S. Loppia, 2015. Lichens as suitable indicators of the biological effects of atmospheric pollutants around a municipal solid waste incinerator (S Italy). Ecological Indicators, 52: 362-370.

Pawlik-Skowronska, P. and M. Bačkor, 2011. Zn / Pb-tolerant lichens with higher content of secondary metabolites produce less phytochelatins than specimens living in unpolluted habitats. Environmental and Experimental Botany, 72: 64-70.

Perraudin, E., H. Budzinski and E. Villenave, 2005. Analysis of polycyclic aromatic hydrocarbons adsorbed on particles of atmospheric interest using pressurised fluid extraction. Analytical and Bioanalytical Chemistry, 383(1): 122-131.

Pitcairn, C., D. Fowler, I. Leith, L. Sheppard, S. Tang, M. Sutton and D. Famulari, 2006. Diagnostic indicators of elevated nitrogen deposition. Environmental Pollution, 144(3): 941-950

Ravindra, K., R. Sokhi and R. Van Grieken, 2008. Atmospheric polycyclic aromatic hydrocarbons: Source attribution, emission factors and regulation. Atmospheric Environment, 42(13): 2895-2921.

Samdudin, M.W., H. Azahar, A. Abas and Z. Zakaria, 2013. Determination of Heavy Metals and Polycyclic Aromatic Hydrocarbons ( PAH ) Contents Using the Lichen Dirinaria picta in Universiti Kebangsaan Malaysia. Journal of Environmental Propection, 4: 760-765.

Samsudin, M.W., L. Din, Z. Zakaria, J. Latip, T. Lihan, A.A. Jemain and F. Samsudin, 2012. Measuring Air Quality using Lichen Mapping at Universiti Kebangsaan Malaysia (UKM) Campus. Procedia - Social and Behavioral Sciences, 59: 635-643.

Sawidis, T., J. Breuste, M. Mitrovic, P. Pavlovic, and K. Tsigaridas, 2011. Trees as bioindicator of heavy metal pollution in three European cities. Environmental Pollution, 159(12): 3560-3570.

Seed, L., P. Wolseley, L. Gosling, L. Davies and S.A. Power, 2013. Modelling relationships between lichen bioindicators, air quality and climate on a national scale: Results from the UK OPAL air survey. Environmental Pollution, 182 : 437-447.

Shukla, V. and D. K. Upreti, 2009. Polycyclic aromatic hydrocarbon ( PAH ) accumulation in lichen , Phaeophyscia hispidula of DehraDun City, Garhwal Himalayas. Environmental Monitoring and Assessment,149: 1-7.

Van der Wat, L. and P.B.C. Forbes, 2015. Lichens as biomonitors for organic air pollutants. TrAC - Trends in Analytical Chemistry, 64: 165-172.

Wegener, J.W.M., M.J.M. van Schaik and H. Aiking, 1992. Active biomonitoring of polycyclic aromatic hydrocarbons by means of mosses. Environmental Pollution, 76(1): 15-18.

Wieczorek, J., S. Sienkiewicz, M. Pietrzak and Z. Wieczorek, 2015. Uptake and phytotoxicity of anthracene and benzo[k]fluoranthene applied to the leaves of celery plants (Apium graveolens var. secalinum L.). Ecotoxicology and Environmental Safety, 115: 19-25.

Will-Wolf, S., S. Jovan and M.C. Amacher, 2017. Lichen elemental content bioindicators for air quality in upper Midwest, USA: A model for large-scale monitoring. Ecological Indicators, 78: 253-263.

Zhou, R., R. Yang and C. Jing, 2018. Polycyclic aromatic hydrocarbons in soils and lichen from the western Tibetan Plateau: Concentration profiles, distribution and its influencing factors. Ecotoxicology and Environmental Safety, 152: 151-158.

Zoungranan, Y., L. Ekou, T. Ekou and K.V.A. Kouadio, 2017. Bioaccumulation Capacity of Cu and Fe on Lichen Parmotrema Dilatatum. European Journal of Scientific Research, 145(3): 346-353. 